\title{
CONSTRAINING THE AGE OF NEOPROTEROZOIC GLACIATION IN EASTERN BRAZIL: FIRST U-Pb (SHRIMP) DATA OF DETRITAL ZIRCONS
}

\section{ANTÔNIO CARLOS PEDROSA-SOARES ${ }^{1}$, UMBERTO GIUSEPPE CORDANI² AND ALLEN NUTMAN ${ }^{3}$}

\begin{abstract}
Detrital zircons extracted from a diamictite-bearing formation of the Macaúbas Group, located within the Araçuaí Belt (Eastern Brazil), were dated using a Sensitive High-Resolution Ion Microprobe (SHRIMP). The youngest reliable measurement sets the upper limit for the age of the glaciation at $950 \mathrm{Ma}$. The main group of zircons (1000-950 Ma) is a good evidence of a magmatic episode, interpreted as related to the rift stage of the Araçuaí-West-Congo basin system.
\end{abstract}

Keywords:

\section{INTRODUCTION}

In Eastern Brazil, glaciogenic diamictite covering areas of the São Francisco Craton are correlated with diamictite-bearing sequences found in orogenic belts that surround this craton (e.g., Karfunkel \& Hoppe 1988). We present U-Pb ages of detrital zircons from the Macaúbas Group, extracted from a diamictitebearing formation that occurs within the Araçuaí Belt (Fig. 1).

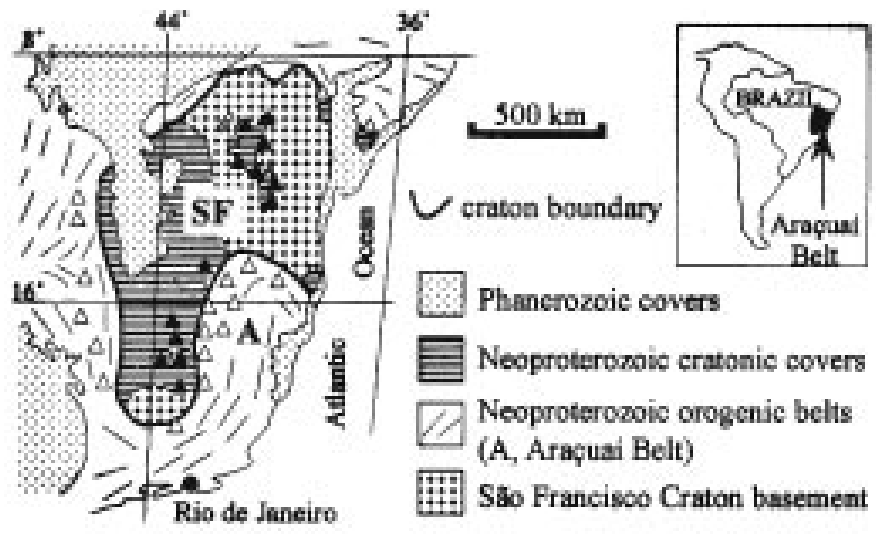

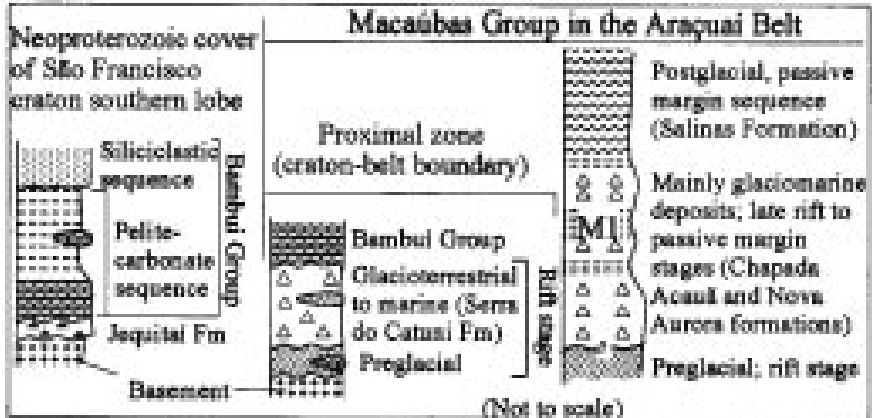

Figure 1 - Location of Neoproterozoic diamictite units in Eastern Brazil (full triangles in cratonic region; open triangles in orogenic belts). Sketch stratigraphic columns show correlation between the diamictite units in the São Francisco Craton (SF) southern lobe and in the Araçuai Belt, with indication of major unconformities (rippled heavy lines). Basement includes Late Paleoproterozoic-Mesoproterozoic supracrustal units. Based in Schobbenhaus et al. (1984).

GEOLOGIC SETTING The Macaúbas Group includes seven formations (Noce et al. 1997), but only five occur within the focused region (Fig. 2). The lower units are the Duas Barras (sandstone, conglomerate), Domingas (pelite, stromatolitic dolomite), Rio Peixe Bravo (sandstone, pelite) and Serra do Catuni (diamictite, sandstone) formations, metamorphosed in greenschist facies. The first three units were deposited in preglacial environments, during the rift stage of the Macaúbas basin.

The Serra do Catuni Formation is the proximal glaciogenic unit of the Macaúbas Group, representing the extension of the glacial sedimentation from the cratonic region (Jequitaí Formation, Fig. 1) into the Araçuaí Belt. Both formations are characterized by diamictite rich in carbonate clasts, and exhibit striking evidence of glacial sedimentation (Karfunkel \& Hoppe 1988, Almeida-Abreu et al. 1997,

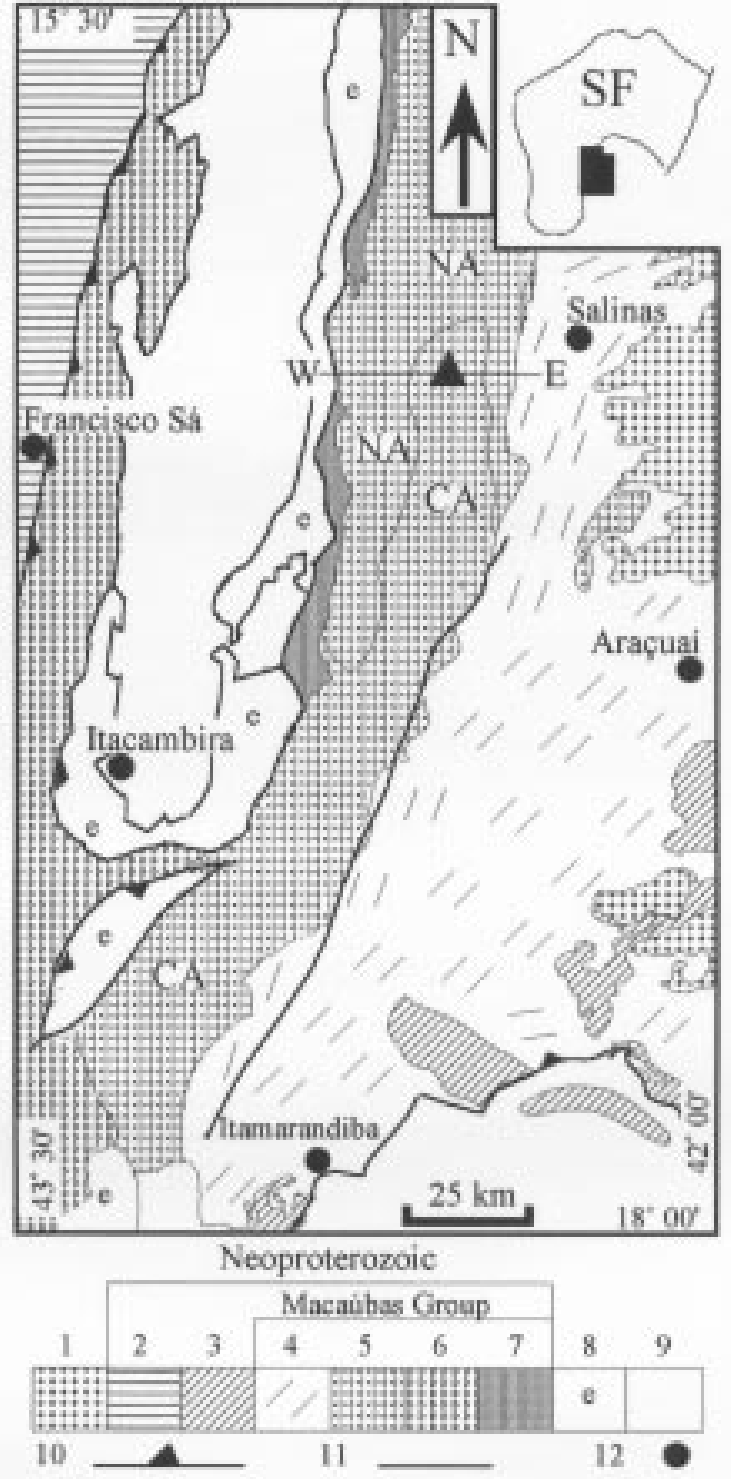

Figure 2 - Geologic map of the Macaúbas Group in the northern sector of the Araçuí Belt (SF-São Francisco Craton), and location of M1 outcrop (triangle). 1-Cambrian granites, 2-Bambuí Group, 3-Capelinha Formation (metapelite, quartzite), 4-Salinas Formation, 5-Chapada Acauã-CA and Nova Aurora-NA formations, 6-Serra do Catuni Formation, 7-Rio Peixe Bravo Formation, 8-Paleoproterozoic-Mesoproterozoic Espinhaço Supergroup, 9gneissic basement, 10-thrust faults, 11-other faults, 12-towns. Modified from Noce et al. (1997).

Martins-Neto 1998, Uhlein et al. 1999). The Serra do Catuni Formation was also deposited during the rift stage of the Macaúbas basin (Noce et al. 1997). 
The Nova Aurora and Chapada Acauã formations record rift to passive margin stages of the Macaúbas basin (Fig. 2). They consist of diamictite, hematitic diamictite with thick layers of (Rapitan-type) iron formation, sandstone and pelite, metamorphosed in greenschist facies (Fig. 3). Cyclic deposition from ruditic to fine-grained sediments with graded bedding testifies sedimentation from debris flows to turbiditic currents (Pedrosa-Soares et al. 1992, Uhlein et al. 1999). Scattered clasts up to one-meter size enveloped by sandy-pelitic rhythmites are evidence of iceberg discharges in the Macaúbas basin. The Salinas Formation records the passive margin stage, and represents a transgressive sequence deposited after the glaciation (Pedrosa-Soares et al. 1992, 1998).

SAMPLING AND U-Pb ANALYTICAL PROCEDURES Only one of the selected samples yielded good zircons for $\mathrm{U}-\mathrm{Pb}$ analysis. The M1 sample was collected from a 3 m thick quartzite layer of a sandy-pelitic unit of the Chapada Acauã Formation, exposed in a road cut of the BR-251 highway, close to a gas station named Curral de

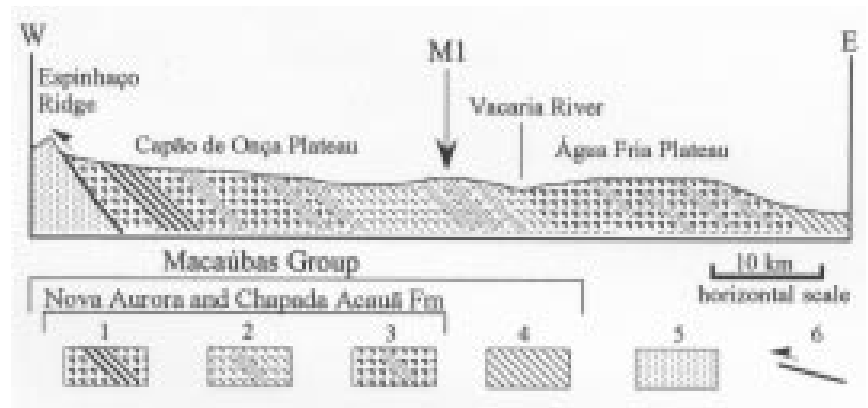

Figure 3 - Location of M1 outcrop in W-E section indicated in Figure 2. Macaúbas Group: 1-diamictite-rich facies with sedimentary iron formation, 2 sandy-pelitic rhythmite facies with quartzite layers, 3-quartzite-bearing diamictite facies, 4-Salinas Formation. 5-Espinhaço Supergroup. 6-fault.

Table 1. SHRIMP U-Pb data for detrital zircons from the Macaúbas Group, Araçuai Belt. Analytical procedures and data assessments in Compston et al. (1984) and Roddick \& van Breemen (1994). U-Th-Pb isotopic ratios and concentrations in unknowns determined using standard Sri Lankan zircon SL13 (572 Ma, $\left.{ }^{206} \mathrm{~Pb} /{ }^{238} \mathrm{U}=0.0928\right) . f^{206} \mathrm{~Pb}$ is proportion of non-radiogenic ${ }^{206} \mathrm{~Pb}$, corrected based on ${ }^{204} \mathrm{~Pb}$; Cumming \& Richards (1975) model. Decay constants and presentday ${ }^{238} U P^{235} U$ ratios in Steiger and Jaeger (1977). * radiogenic $\mathrm{Pb} ;+$ respectively ${ }^{206} \mathrm{~Pb} * \mathrm{P}^{238} \mathrm{U},{ }^{207} \mathrm{~Pb} * p^{235} \mathrm{U}$ and ${ }^{207} \mathrm{~Pb} *{ }^{206} \mathrm{~Pb}$ ages, with errors quoted at 1 sigma level; $\S$ degree of concordance between ${ }^{207} \mathrm{~Pb} * 206 \mathrm{~Pb}$ and ${ }^{206} \mathrm{~Pb} * 238 \mathrm{U}$ ages.

\begin{tabular}{|c|c|c|c|c|c|c|c|c|c|c|c|c|}
\hline Spot & $\begin{array}{c}\mathrm{U} \\
(\mathrm{ppm})\end{array}$ & $\mathrm{Th} / \mathrm{U}$ & $\begin{array}{c}\mathrm{Pb} \\
(\mathrm{ppm})\end{array}$ & $\begin{array}{l}{ }^{204} \mathrm{~Pb} \\
(\mathrm{ppb})\end{array}$ & $\begin{array}{c}\mathrm{f}^{206} \mathrm{~Pb} \\
(\%)\end{array}$ & ${ }^{206} \mathrm{~Pb}^{*}{ }^{238} \mathrm{U}$ & ${ }^{207} \mathrm{~Pb} *{ }^{235} \mathrm{U}$ & ${ }^{207} \mathrm{~Pb} * /{ }^{206} \mathrm{~Pb}$ & $\begin{array}{c}\text { Age } 6 / 38^{\dagger} \\
\text { (Ma) }\end{array}$ & $\begin{array}{c}\text { Age } 7 / 35^{\dagger} \\
\text { (Ma) }\end{array}$ & $\begin{array}{c}\text { Age } 7 / 6^{\dagger} \\
\text { (Ma) }\end{array}$ & $\begin{array}{c}\text { Conc }^{\S} \\
(\%)\end{array}$ \\
\hline 1.1 & 181 & 0.91 & 80 & 268 & 0.001 & 0.3724 & 6.442 & 0.12547 & $2040 \pm 48$ & $2038 \pm 26$ & $2035 \pm 14$ & 100 \\
\hline 2.1 & 133 & 0.40 & 22 & 18 & 0.001 & 0.1637 & 1.630 & 0.07219 & $977 \pm 26$ & $982 \pm 26$ & $991 \pm 50$ & 98 \\
\hline 3.1 & 156 & 0.82 & 69 & 240 & 0.002 & 0.3768 & 6.598 & 0.12701 & $2061 \pm 52$ & $2059 \pm 28$ & $2057 \pm 14$ & 100 \\
\hline 4.1 & 154 & 0.36 & 26 & 21 & 0.002 & 0.1653 & 1.623 & 0.07121 & $986 \pm 26$ & $979 \pm 27$ & $964 \pm 60$ & 102 \\
\hline 5.1 & 137 & 0.37 & 23 & 21 & 0.002 & 0.1618 & 1.637 & 0.07337 & $967 \pm 26$ & $985 \pm 27$ & $1024 \pm 56$ & 94 \\
\hline 6.1 & 134 & 0.47 & 24 & 20 & 0.006 & 0.1714 & 1.633 & 0.06913 & $1020 \pm 29$ & $983 \pm 29$ & $903 \pm 60$ & 113 \\
\hline 7.1 & 262 & 0.40 & 44 & 36 & 0.001 & 0.1653 & 1.646 & 0.07222 & $986 \pm 23$ & $988 \pm 19$ & $992 \pm 29$ & 99 \\
\hline 8.1 & 732 & 0.19 & 284 & 1150 & 0.0001 & 0.3821 & 6.784 & 0.12877 & $2086 \pm 45$ & $2084 \pm 23$ & $2081 \pm 06$ & 100 \\
\hline 9.1 & 217 & 0.41 & 37 & 28 & 0.002 & 0.1676 & 1.634 & 0.07070 & $999 \pm 24$ & $983 \pm 30$ & $949 \pm 77$ & 105 \\
\hline 10.1 & 131 & 0.82 & 59 & 210 & 0.002 & 0.3840 & 6.791 & 0.12827 & $2095 \pm 49$ & $2085 \pm 27$ & $2074 \pm 16$ & 101 \\
\hline 11.1 & 275 & 0.44 & 164 & 1123 & 0.0004 & 0.5326 & 13.870 & 0.18888 & $2752 \pm 75$ & $2741 \pm 44$ & $2732 \pm 44$ & 100 \\
\hline 12.1 & 132 & 0.39 & 23 & 20 & 0.005 & 0.1683 & 1.617 & 0.06970 & $1002 \pm 28$ & $977 \pm 27$ & $919 \pm 55$ & 109 \\
\hline 13.1 & 155 & 0.48 & 27 & 23 & 0.001 & 0.1622 & 1.636 & 0.07315 & $969 \pm 25$ & $984 \pm 31$ & $1018 \pm 74$ & 95 \\
\hline 14.1 & 169 & 0.60 & 31 & 22 & 0.001 & 0.1693 & 1.663 & 0.07126 & $1008 \pm 25$ & $994 \pm 23$ & $965 \pm 43$ & 104 \\
\hline 15.1 & 125 & 0.42 & 21 & 20 & 0.008 & 0.1639 & 1.559 & 0.06896 & $978 \pm 25$ & $954 \pm 28$ & $898 \pm 67$ & 109 \\
\hline 16.1 & 223 & 0.43 & 39 & 30 & 0.0002 & 0.1670 & 1.677 & 0.07283 & $995 \pm 24$ & $1000 \pm 20$ & $1009 \pm 30$ & 98 \\
\hline 17.1 & 36 & 0.69 & 8 & 13 & 0.020 & 0.2019 & 1.988 & 0.07141 & $1185 \pm 69$ & $1111 \pm 81$ & $969 \pm 192$ & 122 \\
\hline 18.1 & 491 & 0.43 & 71 & 114 & 0.022 & 0.1435 & 1.325 & 0.06699 & $864 \pm 30$ & $857 \pm 47$ & $837 \pm 142$ & 103 \\
\hline
\end{tabular}


Varas (Fig. 2 and 3). This outcrop exhibits hematite-sericite quartzite and biotite-garnet-sericite schist in alternating layers. The east-dipping schistosity is roughly parallel to the bedding plane, and is cut by a west-dipping crenulation cleavage. Metamorphism reached the upper greenschist facies.

The zircon concentrates were obtained by conventional methods. $\mathrm{U}-\mathrm{Pb}$ isotopic analyses were performed by using a Sensitive HighResolution Ion Microprobe. SHRIMP zircon analysis is an ideal technique to investigate the age components of clastic rocks, in order to obtain hints on the nature and age of their sources. Although the individual SHRIMP analysis may not be as precise as those obtained by isotopic dilution, the $30 \mathrm{~mm}$ spatial resolution of the SHRIMP enables to select the best preserved zircon domains, minimizing the possible difficulties due to $\mathrm{Pb}$ loss in damaged or metamict zones of zircon crystals.

All analysis yielded reasonably concordant age results (Table 1). Of the 18 individual analysis, 6 were virtually concordant (within 1\%), 4 exhibited normal discordance (up to 5\%), and 8 exhibited reversed discordance, usually within $10 \%$, with only one of the results well over $20 \%$. Because of the reconnaissance nature of this work, the individual analyses of the zircon crystals comprise only four mass scans, increasing somewhat the age uncertainties of the determinations. The values plotted in the histogram (Fig. 4) represent in all cases intermediate age values for the given samples.

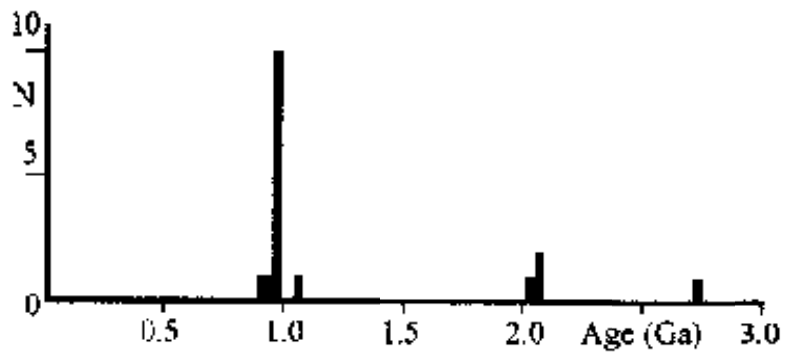

Figure 4 - Histogram of ${ }^{204} \mathrm{~Pb}$ corrected ${ }^{207} \mathrm{~Pb} \mathrm{~F}^{235} \mathrm{U}$ age values of detrital zircons from quartzite (M1) of the Macaúbas Group.

The analyzed zircons are all typical detrital rounded grains (Fig. 5). With the exception of a few pale brown grains, and only one large crystal with a deep red-brown color, the majority of the crystals are colorless to pale yellow. They are usually equant or ovoid-equant, and seem to be structureless, without zoning, inherited cores or evident overgrowth. Some of the grains exhibit inclusions, but most of them seem to be quite fresh and free of alteration and recrystallization features.

Only one crystal (11.1, Fig. 5) yielded an Archean age (2744 \pm 44 $\mathrm{Ma}$ ), a good pale brown, stubby prismatic, concordant zircon. Four zircons yielded Paleoproterozoic very concordant age values between 2030 and $2090 \mathrm{Ma}$ (average value of $2066 \pm 26 \mathrm{Ma}$ ). Three of them $(1.1,3.1$ and 10.1, Fig. 5) are ovoid to equant in shape, and pale yellow to pale brown, and the fourth is the largest deep red-brown crystal (8.1, Fig. 5).

Eleven results plotted in the interval between 950 and $1000 \mathrm{Ma}$ (average value of $983 \pm 10 \mathrm{Ma}$ ). These crystals are colorless to pale yellow, and ovoid-equant to stubby prismatic in shape. Only one zircon (6.1, Fig. 5) corresponds to a reasonably long prismatic crystal. Some detrital zircons from diamictites of the Jequitaí Formation yielded similar ages, obtained by the single grain evaporation method (Buchwaldt et al. 1999).

The age values of spots $17.1(1111 \pm 81 \mathrm{Ma})$ and $18.1(856 \pm 47$ Ma) are suspicious. They exhibit slightly larger ${ }^{204} \mathrm{~Pb}$ corrections, resulting in larger experimental error in the age calculations. The measurement of spot 17.1 is also the one that yielded the extreme reverse discordance, higher than $20 \%$. This crystal is small, colorless, and prismatic, with microfractures possibly filled with alteration products (Fig. 5). Its age result will not be considered further in our interpretation. Spot 18.1 was taken from an edge of an irregular shaped grain, possibly a small portion of a younger overgrowth (Fig. 5). If this is the case, maybe the age value of about 850 Ma could be geologically significant. However, this small grain, ovoid in shape and colorless, seems to belong to the population that yielded the 950-1000 Ma ages.
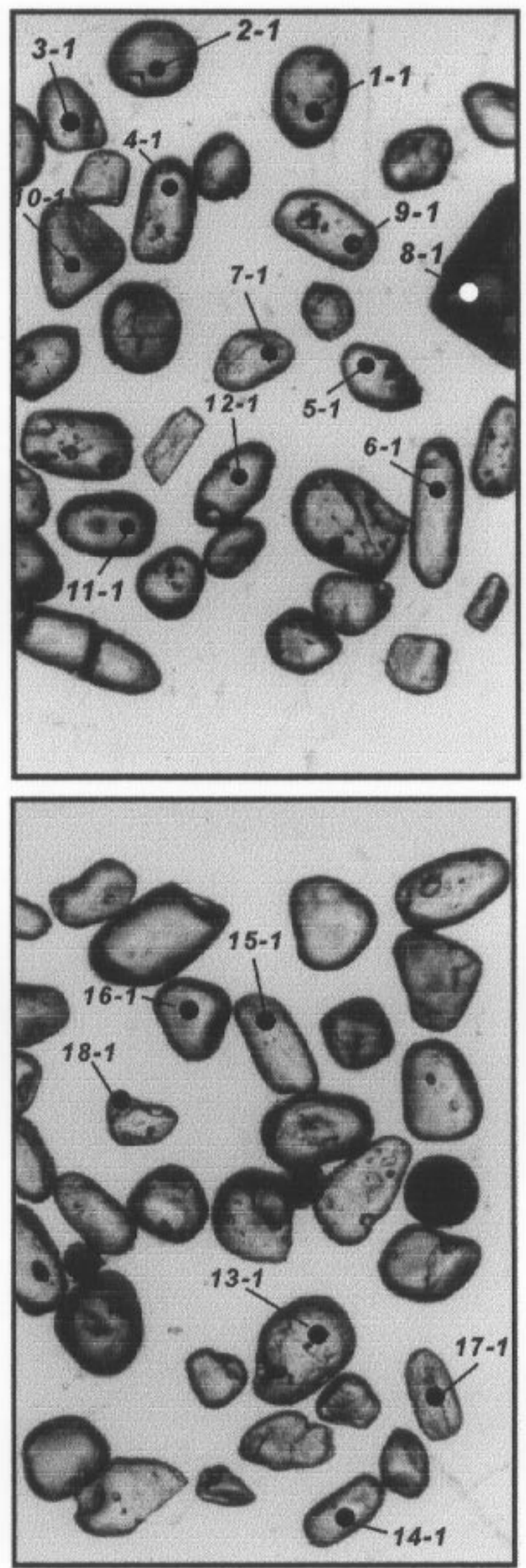

Figure 5 - Zircon crystals from quartzite (M1) of the Macaúbas Group, as mounted for analytical work with indication of SHRIMP spots. 
CONCLUSION For the geological interpretation, it must be remembered that all analyzed zircon grains are detrital, and those belonging to an age group are not to be considered as coming from one single rock unit. The average value calculated for each of the groups shall be envisaged only as an indication for a period of magmatism within a terrain that later became one of the sources for the sedimentation of the Macaúbas Group.

The older group of detrital zircons ( $c a .2066 \mathrm{Ma}$ ) and the oldest analyzed grain ( $c a .2744 \mathrm{Ma}$ ) indicate provenance from sources located in the granite-gneissic basement, where rocks exhibiting similar ages are widespread.

The younger group of detrital zircons (1000-950 Ma, average value of $983 \pm 10 \mathrm{Ma}$ ) constrains the maximum age of the glaciation. The sandy-pelitic unit, from which the M1 sample was collected, represents a quiescent interval of sedimentation between thick marine diamictite deposits. Hence, the youngest reliable measurement sets the maximum age limit of the glaciomarine sedimentation at $950 \mathrm{Ma}$.

The younger zircon group evidences a magmatic episode during early Neoproterozoic. In the Araçuaí-West-Congo Orogen and cratonic surroundings, this episode is related to an extensional tectonic event evidenced by (i) dike swarms that intruded the cratonic basement in the vicinities of the northeastern boundary of the Araçuaí Belt at about $1000 \mathrm{Ma}$ (D'Agrella-Filho et al. 1990; Corrêa-Gomes \& Oliveira 1997); (ii) mafic dikes within the Espinhaço Supergroup in the Araçuai Belt region intruded at about $906 \mathrm{Ma}$ (Machado et al. 1989), and (iii) anorogenic granites and dike swarms of $c a$. 1000-900 Ma that occur in the West-Congo Belt (Djama et al. 1992, Vicat \& Pouclet 1995). Although lacking sedimentary transport evidence, the Borborema Province, where magmatic rocks formed during the Cariris Velhos Event (ca. 1100-950 Ma; Brito-Neves et al. 1995), is an alternative source for the younger zircon group. The oldest magmatic arcs within the Brasília Belt (900-850 Ma; Pimentel et al. 1999) are unlikely sources for the younger zircon group.

We suggest that the main sources of the younger zircon group were magmatic rocks, perhaps sub-volcanic, formed during the rift stage of the Araçuaí-West-Congo basin system. We shall consider that intense erosion may have taken place on the uplifted shoulders of such precursor rift valleys, and on the internal horsts. Bimodal volcanic rocks may have supplied sediments to the grabens, and almost entirely eroded. In subsequent stages, these sediments may have suffered reworking in the basin by, for instance, debris flows and turbiditic currents in glaciomarine environment.

Acknowledgments This paper was supported by Conselho Nacional de Desenvolvimento Científico e Tecnológico (CNPq) and Fundação de Amparo à Pesquisa de Minas Gerais (FAPEMIG). To Danilo Ferreira, LOPAG-UFOP and CPMTC-UFMG for the preparation of zircon concentrates. To two anonymous referees of Revista Brasileira de Geociências for their helpful suggestions.

\section{References}

Almeida-Abreu P.A., Renger F.E., Lindenberg S.F., Silva M.F.L., Góes H. 1997. A Bacia Macaúbas no nordeste da Serra do Espinhaço Meridional, Minas Gerais. In: SBG, Simp. Geol. Minas Gerais, 9, Ouro Preto, Anais, 12-13

Brito-Neves B.B., van Schmus W.R., Santos E.J., Campos-Neto M.C., Kozuch M. 1995. O Evento Cariris Velhos na Província Borborema: Integração de dados, implicações e perspectivas. Rev. Bras. Geociências, 25: 279-296

Buchwaldt R., Toulkeridis T., Babinski M., Santos R., Noce C.M., Martins-Neto M., Hercos C.M. 1999. Age determination and age related provenance analysis of the Proterozoic glaciation event in central-eastern Brazil. In: Servicio Geologico Minero Argentino, South American Symposium on Isotope Geology, 2, Cordoba, Actas, 387Argention
390

Compston W., Williams I.M., Myer C. 1984. U-Pb geochronology of zircons from lunar breccia 73217 using a sensitive high mass-resolution ion microprobe. J. Geophysical Res., 89B: 525-534

Corrêa-Gomes L.C., Oliveira, E.P. 1997. O enxame radial gigante de diques máficos da província Bahia-Congo. In: SBG, Simp. Nac. Estudos Tectônicos, 5, Pirenópolis, Anais, 52-55

Cumming G.L., Richards J.R. 1975. Ore lead in a continuously changing Earth. Earth and Planetary Sci. Letters, 28: 155-17

D'Agrella-Filho M.S., Pacca I.G., Teixeira W., Onstott T.C., Renne, P.R. 1990 Paleomagnetic evidence for the evolution of Meso to Neoproterozoic glaciogenic rocks in central-eastern Brazil. Palaeogeography, Palaeoclimatology, Palaeoecology, 80: 255-265

Djama L.M., Leterrier J., Michard A. 1992. Pb, Sr and Nd isotope study of the basement of the Mayumbian Belt (Guena gneisses and Mfoubou granite, Congo): Implications for the Mayumbian Belt (Guena gneisses and Mroubou granite, Congo): Imp

Karfunkel J., Hoppe A. 1988. Late Proterozoic glaciation in central-eastern Brazil: Synthesis and model. Palaeogeography, Palaeoclimatology, Palaeoecology, 65: 1-21

Machado N., Schrank A., Abreu F.R., Knauer L.G., Almeida-Abreu P.A. 1989. Resultado preliminares da geocronologia U-Pb na Serra do Espinhaço Meridional. In: SBG,
SB. Simp. Geol. Minas Gerais, 5, Belo Horizonte, Anais, 171-174

Martins-Neto M.A. 1998. Mantle plume, rifting and the early Neoproterozoic glaciation in the São Francisco Craton and Araçuaí Belt, Southeastern Brazil. In: Universidade Federal de Ouro Preto, Int. Conf. Basement Tectonics, 14, Ouro Preto, Abstracts, 32 34
Noce C.M., Pedrosa-Soares A.C., Grossi-Sad J.H., Baars F.J., Guimarães M.L.V., Mourão M.A.A., Oliveira M.J.R., Roque N.C. 1997. Nova subdivisão estratigráfica regional do Grupo Macaúbas na Faixa Araçuaí. In: SBG, Simp. Geol. Minas Gerais, 9, Anais, 29-31

Pedrosa-Soares A.C., Noce C.M., Vidal Ph., Monteiro R.L.B.P., Leonardos O.H. 1992. Toward a new tectonic model for the Late Proterozoic Araçuaí (SE Brazil)-West Congolian (SW Africa) Belt. J. South American Earth Sci., 6: 33-47

Pedrosa-Soares A.C., Vidal Ph., Leonardos O.H., Brito-Neves B.B. 1998. Neoproterozoic oceanic remnants in Eastern Brazil: Further evidence and refutation of an exclusively ensialic evolution for the Araçuaí-West-Congo Orogen. Geology, 26: 519-522

Pimentel M.M., Fuck R.A., Botelho N.F. 1999. Granites and the geodynamic history of the Neoproterozoic Brasília Belt, Central Brazil: a review. Lithos, 46: 463-483

Roddick J.C., van Breemen O. 1994. U-Pb zircon dating: a comparison of ion microprobe and single grain conventional analysis. Geological Survey Canada Current Research, 8: $1-9$

Schobbenhaus C., Campos D.A., Derze G.R., Asmus H.E. (eds.) 1984. Geologia do Brasil. Brasília, Departamento Nacional da Produção Mineral, 501 p.

Steiger R.H., Jaeger E. 1977. Subcommission on Geochronology: Convention on the use of decay constants in geo and cosmochronology. Earth and Planetary Sci. Letters, 36: 359-362

Uhlein A., Trompette R., Alvarenga C.J.S 1999. Neoproterozoic glacial and gravitational sedimentation on a continental rifted margin: The Jequitaí-Macaúbas sequence (Minas Gerais, Brazil). J. South American Earth Sci., 12: 435-451

Vicat J., Pouclet A. 1995. Nature du magmatisme lié à une extension prè-panafricaine: Les dolérites des bassins de Comba et de Sembé-Ouesso (Congo). Bull. Soc. Géol. France, 166: 355-364 